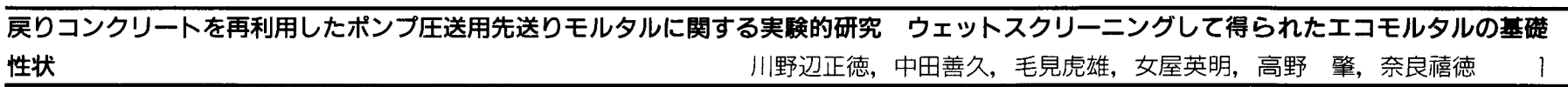

長尾覚博 [(株) 大林組技術研究所化学研究室 主席研究圓・工博 $]$

我が国における，生コンクリートの年間出荷量は平成10年度にお いて約 1 億 5,300 万 $\mathrm{m}^{3} に$ 及び, 戻りコン, 残りコンの年間推定 500 万トンは生コンクリート出荷量の $3 \%$ 強となっている。建設廃菓物 の発生抑制およびリサイクルの推進が問われている現在, さまざま な視点からの対応あるいは技術開発が必要であり，そのような背景 から既存技術を基に新しいリサイクル技術を展開しようと試みてい る本報告の姿勢は大いに評価されるべきものである。

報告ではモルタルを回収し，先送りモルタルとして再利用する技 術を提案しているが, 同時に発生するスラッジは廃葉されており, 環境負荷低減という観点で疑問の残る面もある。

スラッジの再利用法や廃寨物を出さない粗骨材のリサイクル手法 などを考虑したトータル技術として，戻りコン，残りコンの全量有 効利用を目指した研究開発の推進を期待する。
森永 繁 [九州東海大学工学部建築学科 教授.工博 $]$ 生コンプラントで発生する戻りコン・残りコンに着目し, 資源の 有効利用および建設副産物発生抑制の観点から先送りモルタルとし て再利用しようとする試みは, 新たな取り組みであり, 興味深い報 告である。モルタルは, コンクリートに比べ明確な品質規格が存在 しないため取扱いが踈かにされがちだが，建設現場においては，や むを得ず軀体に打ち込まれることもあるため，品質および取扱いに 注意を払う必要がある。本報告では, エコモルタルが軀体に打ち込 まれることも考慮し，その性状を明らかにしてある。ただし，今回 は, 試験室内における基礎性状ということでポンプ圧送についての 検討がないためもの足りない。続報でポンプ圧送性の確認も含め, 実機圧送による検討を行なってもらいたい。エコモルタルの製造方 法が確立されれば, 生コンプラントにおける戻りコン・残りコンの 処理問題はもとより, 建設副産物の大幅な低減に罊がるだろう。

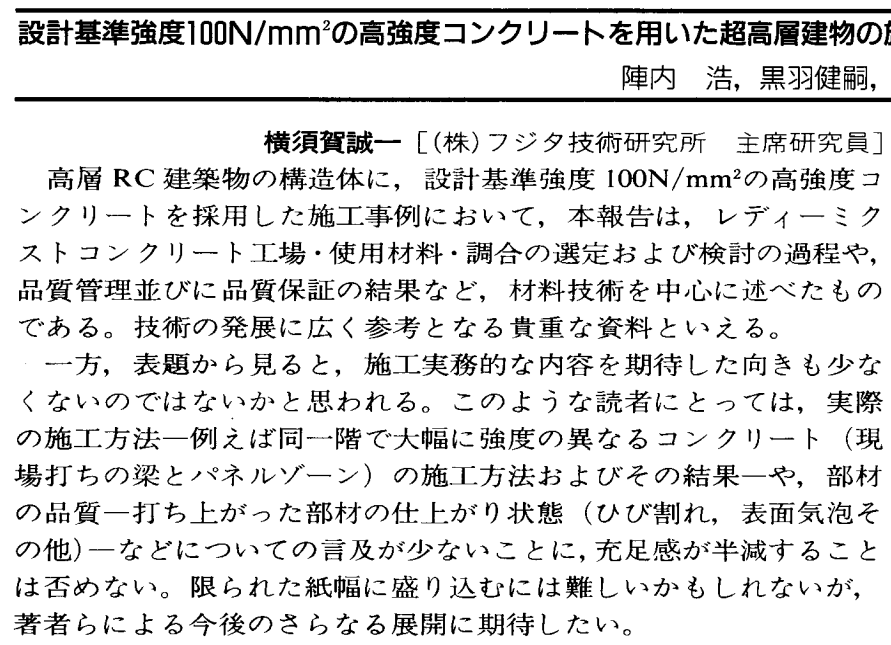

哲, 黒岩秀介, 川端一三, 原 孝文, 稲津秀明, 後藤和正 7

福士 勳 $[($ 株) 都市整備プランニング 取締役技術開発本部長 $]$ 設計基準強度 $100 \mathrm{~N} / \mathrm{mm}^{2}$ の高強度コンクリートを採用し, 超高層 $\mathrm{RC}$ 造住宅の問題点とされていた居住空間の改善を図ったことは画 期的なことである。調合強度にして $120 \mathrm{~N} / \mathrm{mm}^{2}$ を越えるような高強 度コンクリートの製造・施工は，現状において限界に近いものであ る。今回その実用化を可能にしたのは，執筆者らの長年にわたって 実施してきた各種要素技術の開発研究の蓄積によるものであり，本 報告はいわばその集大成ともい之る。これまでの努力に対し敬意を 表するものである。

本報告は超高層 RC 造住宅 2 棟の実施工例であるが，むしろ何れ か 1 棟にしばってより詳細な知見を述べてほしかったと思う。例之 ば, 結合材を 3 成分のプレブレンド品とした技術的経緯, 低温時にお けるコンクリートの凝結性状, 構造体強度の管理材令を 56 日とした 理由, さらには水和発熱による構造体コンクリートの温度上昇分布 などについて知り得たいところである。

\title{
建築構造物の解体に伴い発生するコンクリート塊のリサイクルシステム 再生粗骨材現場投入方式による再生コンクリートの製造
}

\author{
道正泰弘, 成川匡文, 菊池雅史, 増田 彰, 大島 豊, 江口 清, 中込 昭, 寺西浩司 13
}

\begin{abstract}
大野義照 [大阪大学工学研究科建築工学専攻 教授・工博] 天然資源の枯渇, $\mathrm{CO}_{2}$ 削減に対する社会の要請, 産業廃率物処分場 の逼迫等の状況に対応するように再生コンクリートに関する研究が 最近急速に進み, 普通コンクリートと比較して遜色のないものが得 られるようになってきた。一方，実際に建築物に使用されている再 生コンクリートの量は, 残念ながら非常に僅かである。その理由と して, 本報告で紹介されている市中プラントの対応不可能理由の他 に, 解体物件毎に骨材が異なることによる市中プラントにおける骨 材管理の問題, 経済性の問題, さらに一般の理解不足がある。

このような現況の中で，本報告は，大規模建築物の建替えという 同一敷地内で解体と新筑が同時期に行われる特殊な条件下ではある が, 1 つの解決策を提案している。 $\mathrm{CO}_{2}$ の排出量と経済性についても 検討を行っている。このような方法によって再生コンクリートの建 築構造体への利用実績が增え, 再生コンクリートに対する建築関係 者の理解が增すことが期待される。
\end{abstract}

阿部道彦 [建設省建築研究所第 2 研究部無機材料研究室 室長・工博]

再生コンクリートの実用化に関する研究はこれまで多数行われて いるが，そのほとんどは再生骨材を生コン工場まで運搬し，そこで 再生コンクリートを製造しようとするものであり，通常の骨材を使 用した生コンを購入し，それに現場で再生粗骨材を投入するという 筆者らの提案する方法は新たな解を与えるものとして評価できる。

購入する生コンの調合は使用する再生粗骨材の品質に基づき, 相 対品質值法によって発注者によって指定されることになり, 再生粗 骨材の置換率によっては生コンの規格外品として発注せざるを得な い場合も生じるであろう。この場合, 生コン工場側で保証すべき品 質項目の範囲と方法が検討されなければならない。当報告では, ベー スコンクリートの品質の試験結果については記載がないが, 参考の ため示されているとよかった。また， べースコンクリートの受入れ 後は返却ができないので, 再生粗骨材を現場で投入した後に所定の 品質が得られなかった場合，スランプや空気量を調整するために混 和剂を使用する必要も生じるであろう。実用化への課題は多いが, 今後の展開を期待したい。 